\title{
IT USERS' AWARENESS ABOUT THE NEED OF STRONG PASSWORDS CREATION
}

\author{
KONECKI, M.; OREHOVACKI, T. \& STAPIC, Z.
}

Abstract: Business world today, along with belonging processes, is becoming more and more dynamic and complex. Information as a vital resource has to be adequately protected. Security generally has become an issue of great importance. One of the security mechanisms and actual security issues is the problem of strong passwords creation. This problem is directly connected with the users' awareness about strong passwords creation. In our research we have analyzed the strength of passwords created by experienced IT users. Known password strength determination algorithms have been used in our analysis. Two hypotheses were created and tested using analysis of gathered data, correlation and regression. Conclusions and possible resolutions are presented and discussed.

Key words: password, strenght, security, awareness
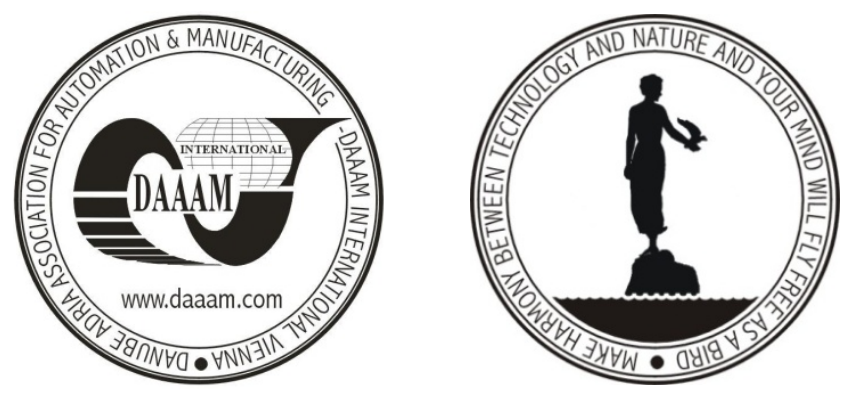

Authors' data: Konecki, M[ario]; Orehovacki, T[ihomir]; Stapic, Z[latko], Faculty of Organization and Informatics, Pavlinska 2, 42000, Varazdin, HR, mario.konecki@foi.hr, tihomir.orehovacki@foi.hr, zlatko.stapic@foi.hr

This Publication has to be referred as: Konecki, M[ario];Orehovacki, T[ihomir];Stapic, Z[1atko] (2008). It Users' Awareness about the Need of Strong Passwords Creation, Chapter 33 in DAAAM International Scientific Book 2008, pp. 387-394, B. Katalinic (Ed.), Published by DAAAM International, ISBN 978-3901509-66-7, ISSN 1726-9687, Vienna, Austria

DOI: $10.2507 /$ daaam.scibook.2008.33 